\title{
Editorial
}

A relação conhecimento e produção de meios de vida é parte da constituição do ser humano como tal. Até o século XV, a elaboração do tipo de conhecimento que hoje podemos chamar de ciência esteve ligada à filosofia; é somente a ascensão burguesa que torna possível a constituição de um campo de conhecimento mais objetivo e passível de verificação chamado ciência. Tais transformações são de ordem tão significativa que o conjunto das invenções e descobertas são conhecidas como a revolução científica dos séculos XV e XVI.

As repercussões dos avanços científicos na produção permanecem pontuais até a revolução industrial do século XVIII.

A indústria moderna que resulta das transformações da manufatura, constituindo um sistema de máquinas complexo tende a submeter progressivamente a ciência às suas necessidades, como afirma Marx: "o instrumental de trabalho, ao converter-se em maquinaria, exige a substituição da força humana por forças naturais e da rotina empírica pela aplicação consciente da ciência" (MARX, 1989, p. 439).

Esta incorporação do conhecimento científico se dá de forma semelhante ao que ocorre com as forças naturais e as forças produtivas resultantes da cooperação e da divisão do trabalho. Depois de descobertas, as invenções não custam mais nada, daí que sejam "protegidas" para que seu uso se subordine aos interesses do capital ou não se dissemine, comprometendo o desenvolvimento geral.

A maquinaria, como resultado de inúmeros avanços científicos e técnicos, também presta um serviço semelhante aos recursos naturais:

"Quanto maior a força produtiva das máquinas em relação à dos instrumentos manuais, tanto maior o serviço gratuito que prestam em comparação com o que se obtém desses instrumentos. Só com a indústria aprende o homem a fazer o produto de seu trabalho passado, o trabalho já materializado, operar em grande escala, gratuitamente, como se fosse uma força natural" (Ibid.p. 442).

A segunda onda de transformações no modo de produção capitalista ocorre no final do século XIX com a formação do capital financeiro e dos monopólios. Neste momento, a invenção passa a ser incorporada às atividades rotineiras dos trusts; colocando sob suas determinações a oportunidade ou não da disseminação de determinado invento ou procedimento.

Este processo se intensifica a partir da II Guerra Mundial com a consolidação da pesquisa e do desenvolvimento em atividade sistemática no interior das empresas e a formação de setores industriais diretamente ligados à ciência, como indústria nuclear, petroquímica, informática e outros: " $\mathrm{E}$ isto supunha um fato totalmente novo para a ciência. Ela passava a ser um campo de interesse direto e imediato do capital e uma atividade econômica indissoluvelmente ligada ao funcionamento da economia" (SANTOS, 2015, p. 9).

No momento de crise orgânica do capital em que vivemos, a ciência e a educação "passam a dominar a composição orgânica do capital e o desenvolvimento do processo de produção e trabalho, tornando o paradigma de valor da relação capital, 
o tempo socialmente necessário, profundamente estreito para mensurar o valor que incorporam, como general intellect $\mathrm{e}$ forças produtivas sociais, aos produtos" (MARX apud BEVILAQUA, 2015, p. 9).

Com base nesse panorama das revoluções científicas, realizou-se o Seminário de instalação da Reggen (Rede de Economia Global e Desenvolvimento Sustentável) na UERJ (Universidade do Estado do Rio de Janeiro no final de junho. Desse encontro publicamos três artigos sobre a relação conhecimento e modo de produção.

$\mathrm{O}$ artigo de Monica Bruckman, Recursos naturais, pensamento estratégico e soberania na América Latina, aborda a complexidade da estratégia das forças sociais que enfrentam a política de desapropriação dos recursos naturais e territórios, destacando a crescente militarização da América Latina com o efetivo militar estadunidense à frente.

$\mathrm{O}$ artigo de Daniel Roedel, A participação social mediada pelas tecnologias de informação e comunicação - TIC, aborda o uso das tecnologias de informação e comunicação pelos movimentos sociais, destacando seu potencial de mobilização, bem como restrições. Discute o Marco Civil na Internet como importante instrumento de apoio à participação social.

O ensaio de Zacarias Gama, A categoria mediação em Hegel, Marx e Gramsci: para suprimir ruídos conceituais, tem como alvo a categoria mediação definida por Hegel e aqui tomada como objeto com a intenção de apreender o seu significado filosófico. O que justifica tal esforço é a tentativa de superar uma concepção que se tem dela na atualidade, regra geral como sinônimo de simples intermediação entre duas coisas.

$\mathrm{O}$ artigo Leviatã de Thomas Hobbes: direito à resistência e estado de transição, de Aluisio Pampolha Bevilaqua, tem por objetivo oferecer um novo olhar sobre a obra clássica Leviatã ou Matéria, Forma e Poder de Um Estado Eclesiástico e Civil, de Thomas Hobbes. Sustenta a hipótese de que as noções de soberania e liberdade transcendem a ideia de uma forma autoritária de governo feudal ou capitalista.

Pedro Germano, em Acerca das posições de Portugal na Europa e no Mundo / Crónicas independentes de Lisboa, analisa Portugal hoje no quadro de degradação exponencial das relações entre Estados, Federações, Uniões e simples Associações, todos esses conjuntos muito ocupados em dar seguimento às orientações das potências dominantes.

O trabalho de Fabien Tarrit, Sobre a orientação econômica do partido da Frente Nacional (Front National), relaciona a Frente Nacional (FN) francesa e as condições econômicas e sociais do país. Para defender o seu eleitorado tradicional, a pequena burguesia (artesãos e comerciantes), enfraquecidos pela competição, a FN defende o Estado forte limitado às suas funções repressivas.

$\mathrm{O}$ artigo $A$ Educação das relaçôes étnico-raciais e a Sociologia da Infância: contribuições da arte africana para iniciar as rodas de conversa, de Edmilson dos Santos Ferreira, Deise Marins Alcântara e Danielle Minioli Ferreira identifica as estratégias adotadas na prática docente em Educação Infantil acerca da Educação das Relações Étnico-raciais na perspectiva de Lei 10.639/2003.

$\mathrm{O}$ artigo Vila Real é uma leitura do romance de mesmo nome de João Ubaldo Ribeiro, analisando-o como uma narrativa "performática" A partir de tal perspectiva, são observadas questões relacionadas à identidade cultural e ao sistema de identificação coletiva de um grupo de camponeses expropriados.

Wilson Roberto Ferreira, em Cinema e Acontecimento Comunicacional: a experiência cinematográfica pode ser transcendente? , afirma que o cinema traria dentro de si a poten- 
cialidade em transcender a si mesmo e mudar vidas de espectadores ao transformar a experiência estética em acontecimento. $\mathrm{O}$ cinema é um sintoma da sociedade, mas, por outro lado, é um elemento operacional do contínuo midiático.

O debate sobre o fascismo tem urgência em meio a talvez mais grave crise da história do capitalismo. A resenha de Vinicius Ramos, do livro Sombras autoritáriase totalitárias no Brasil: integralismo, fascismo e repressão política, organizado por João Fábio Bertonha, procura contribuir com este debate.

A entrevista de Frei Alamiro recupera momentos da história recente de nosso povo e valoriza a persistência em ideais de mudança e luta pela paz e pela justiça, como as greves de São Bernardo e ações para salvar vidas da repressão no Brasil e na América Latina.

Como a história das revoluções aponta, a superação de crises e advento de um novo modo de produção tem como pressuposto o desenvolvimento do conhecimento e da ciência. Hoje a contradição entre privatização de lucros e socialização crescente da produção coloca a ciência e a educação como âncoras de novo paradigma social e de formação do ser humano novo.

\section{Comissão de Edição}

\section{Referências}

BEVILAQUA, Aluisio Pampolha. A crise orgânica do capital: o valor, a ciência e a educação. Ciência छ Luta de Classes, v. 9, n. 10, jan/jun 2015, pp. 6-13.

MARX, Karl. O Capital.13a ed. Livro 1º, v. 1 Trad. Reginaldo Sant'Anna. Rio de Janeiro: Bertrand, 1989.

SANTOS, Theotonio dos. A Revolução Científico-Tecnológica, a Nova Divisão Internacional do Trabalho e o Sistema Econômico Mundial Theotônio Dos Santos. http://www.reggen.org.br/midia/documentos/arevocienttecno.pdf. Captado em 26 de julho de 2015. 